\title{
DISTRIBUTION AND SALINITY RANGES OF ZOOPLANKTON ORGANISMS AT EL-FAYOUM DEPRESSION (EL-FAYOUM- EGYPT)
}

\section{Adel A. A. Mageed}

National Institute of Oceanography and Fisheries, 101 Kasr AL-Ainy st., Cairo, Egypt

KEY WORDS : Salinity ranges, Zooplankton, Qaroun and Wadi EL-Rayan Lakes, EL-Fayoum depression.

(Received Feb. 25, 1998)

\section{ABSTRACT}

$\mathrm{D}$ istribution and salinity ranges of the different zooplankton species at $\mathrm{El}$ Fayoum depression (El Wadi drain, Wadi El-Rayan Lakes, Fish Farms, Lake Qaroun, and EMISAL company ponds were discussed 18 species of Protozoa, 39 of Rotifera, 10 of Cladocera, 9 of Copepoda and only one Branchiopod were found, Moreover, the Tardigrad Macrobiotus macronyx and the Ostracod Cyprideis torosa in addition to the larvae of some benthic invertebrates were also obtained.

Water of the studied area had a salinity range from 1.7 to $322 \%$. In distribution, the species numbers were mostly decreased with increasing salinity. Some species were found to be euryhaline as Brachionus plicatilis (1.7-127.7\%), Hexarthra oxyuris (2.5-73.7\%o), Keratella tropica and $K$. valga ( $1.7-42 \%$ for the two species ), while all the Cladocera were stenohaline. On the other hand, thirteen species were endemic to its area.

\section{INTRODUCTION}

Fayoum depression lies about $90 \mathrm{Km}$ south west of Cairo. The depression has three lakes; Lake Qaroun and two Lakes at Wadi ElRayan.The drainage water of the agricultural lands of El Fayoum governorate goes to Lake Qaroun through two main drains (EI Wadi and Bats ) conveying about $93 \%$ of the total amount of drainage water to the lake in addition to twelve other small drains. Wadi El-Rayan Lakes gain 
their water through a branch from $\mathrm{El} \mathrm{Wadi}$ drain which inflows in the first lake of Wadi EL-Rayan

The drainage water leads to great leaching of salts, each gram of salt ends up either in Wadi El-Rayan and Qaroun Lakes. Salinity of Lake Qaroun increased vigorously with time, from about $12 \%$ in 1922 up to $30 \%$ in 1985 ( Payne, 1986). It reached to about $42 \%$ during 1994 (Sabae, 1996). In Wadi El-Rayan Lakes, salinities were 2.5, 3, and $4.5 \%$ at the first lake, connecting canal and the secand lake respectively (Rabeh, 1996).

During 1980's, the Egyptian Salts and Minerals Company [EMISAL] was constructed to extract the different dissolved salts from Lake Qaroun. Until now, it is extracting anhydrus Sodium Sulphate only. The lake water is withdrawn to a series of four ponds connected to each other, the first one at the lake while the fourth one is connected to the factory of the salt extraction. The salinity in the four ponds is higher than that of Lake Qaroun especially the fourth one.

In the recent years attention is turned towards fish farming in El Fayoum governorate. More than sixty Fish Farms began during 1980's. The main water sources of these farms is the agricultural drainage water. The salinity of these farms ranges from 5.2 to $18 \%$ (Mageed, 1996 ).

Zooplankton of El Fayoum depression was studied by many workers. Zooplankton of Wadi El-Rayan was studied by Boraey (1978), Khali (1984), Saleh (1984) and El Shebrawy (1993). These studies have concluded that no sharp changes were recorded from year to the other.

Zooplankton of Qaroun Lake was studied by Wimpenny and Titterington (1936), who reported that most of the species are fresh water organisms. Girgis (1960) recorded the marine copepods as abundant. Naguib (1961), El Maghraby \& Dowidar (1969), Khalil (1978), Abdel Malek \& Ishak (1980), Dowidar \& El Nady (1982), Khalifa (1994), and Mageed (1996) observed that, the lake harboured the marine forms only, some of the species are transported to the lake through the transplantation of the Mullet fry from the Mediterranean sea. 
Zooplankton of EMISAL ponds was studied for the first time, whereas that of El Fayoum Fish Farms was studied by Mageed (1996) Zooplankton plays a critical role in the ecology of the aquatic systems by serving as links between the various trophic levels (Benthos and Nektons ). Zooplankton suffers from continuous increases of salinity in EL Fayoum depression. So, the present work aims to reveal the impact of salinity on distribution and diversity of zooplankton in different localities of El Fayoum depression.

\section{MATERIAL AND METHODS}

\section{A - Geography of the study areas and sampling stations (Fig.1) :}

1- El Wadi drain : It collects the agricultural drainage water of El Fayoum governorate. It is divided into two branches, one to Lake Qaroun and the other to Wadi El-Rayan Lakes. Two stations were chosen from El Wadi drain, one on Lake Qaroun and the second at the first Lake of Wadi ElRayan Lakes.

2- Wadi El-Rayan Lakes: They lie in the Western desert (about $150 \mathrm{Km}$ from Cairo ). They comprise two lakes, the first one has an area of about 63 $\mathrm{Km}^{2}$ while the second of about $110 \mathrm{~km}^{2}$. Between the two lakes, there is a shallow connecting canal covered with emerging macrophytes. Three stations in the first lake, five stations in the second lake and one in the connecting canal were chosen to represent Wadi El-Rayan Lakes ecosystem.

3- Fish Farms: Ten ponds of El Fayoum Fish Farms were chosen to represent the different localities of the farms which lie beside Lake Qaroun.

4- Lake Qaroun: It has an area of about $240 \mathrm{~km}^{2}$ at a level of $44 \mathrm{~m}$ below the mean sea water level, with a maximum depth of $8.2 \mathrm{~m}$. It lies in the western desert ( about $90 \mathrm{~km}$ Southwest of Cairo ). Five stations were chosen to represent the lake area; two at the eastern part, one at the middle and two at the western part. 
5- EMISAL ponds: They are four ponds that lie inside the Egyptian Salts and Minerals Company beside Lake Qaroun at Shakshouk Village. The four ponds have surface area of 526, 250,334 and 151 Feddans with depths of $1.60,1.64,2.30$ and $2.60 \mathrm{~m}$, respectively.

Three samples were collected from each pond; the first at the inlet, the second at the middle and the third one at the outlet of the pond.

B - Methods of collection, Preservation, identification and calculation:

The samples were collected monthly during 1996 at El Wadi drain, Wadi El-Rayan Lakes and Lake Qaroun. At El Fayoum Fish Farms, the samples were collected from May to October 1996 (during the fish farming season). whereas, EMISAL samples were collected seasonally during 1996. 100 liters of lake surface water were filtered through $55 \mu$ meter (mesh size) plankton net to give more exact quantitative samples of zooplankton. The samples were fixed by $4 \%$ neutral formalin and identified under Nekon biocular research microscope.

The data of zooplankton numbers were pooled together inside each water mass to give the number of organisms $/ \mathrm{m}^{3}$ at each water mass.

\section{C - Salinity determination : -}

Salinity of Wadi El-Rayan Lakes were cited from Rabeh (1996), of Fish Farms from Mageed (1996), of Lake Qaroun from Sabae (1996), whereas other salinities were determined by silver nitrate method according to standard methods of APHA et al (1992), they.were expressed as $\mathrm{gmi}^{-1}\left(\%_{0}\right)$

\section{D - Statistical analysis:}

Index of biotal dispersity and Similarity index were applied as in Green (1971). Diversity index and Equitability were calculated according to Shannon and Weaver (1963), while Dominance was calculated according to Mc Naughton (1968). 
depression (EL-Fayoum-Egyt))

\section{RESULTS}

Salinity of the first Lake of Wadi El-Rayan was slightly higher than of El Wadi drain but the second lake was about double of the first lake salinity. Fish Farms had a wide range of salinity variations $(5.2-18 \%$ ). Lake Qaroun has high salinity ( $42 \%_{0}$ ), whereas the ponds of EMISAL were hypersaline especially the fourth one (Table 1).

Seventy nine species of zooplankton and their different developmental stages in addition to the larvae of some benthic invertebrates were recorded at El Wadi Drain, Wadi El-Rayan Lakes, El Fayoum Fish farms, Qaroun Lake and EMISAL pond as shown in table (2).

The adult forms of zooplankters belong to four major groups namely: Protozoa, Rotifera, Cladocera and Copepoda and three minor groups: Branchiopoda, Ostracoda and Tardigrada.

The fish farms, Qaroun Lake and the first pond of EMISAL (EP $)$ had the highest number of zooplankton individuals ( 599922, 333410 and 775425 organisms $/ \mathrm{m}^{3}$ respectively ) whereas the lowest counts were recorded at El Wadi drain and $\mathbf{E P}_{4}$.

The highest diversity index of zooplankton was observed at El Wadi drain, the first Lake of Wadi El-Rayan Lakes and their connecting canal. By applying the index of biotal dispersity (TBD) on the data of each group; Rotifera was the most dispersed group among the major groups while Protozoa was the lowest dispersed group. The following is the distribution of the recorded groups:

\section{1 -Protezoa:}

It was represented by eighteen species, twelve of them were restricted to Lake Qaroun (salinity of $42 \%$ ), some species are stenohaline as Centropyxis aculeata and Arcella discoids (salinity ranges of 1.7-18 and 1.7-4.5\%o respectively). On the other hand, some species are euryhaline as Textularia sp, Globigerina sp., Euplotes vannus and Tintinnopsis kofoidi ( salinity ranges of 1.7-42 \%o for the first two species, and 4.5-73.7 and 42- 
$127.7 \%$ for the second two species respectively). Protozoa has disappeared totally at salinities higher than $127.7 \%$.

The maximum counts of Protozoa were observed at Lake Qaroun due to the flourishing of Leprotintinnus botnicus and Helicostomella subulata, that totally represented $57.2 \%$ of all protozoan organisms at El Fayoum depression. As regard to similarity test, the first lake of Wadi ElRayan, Ep3 and Ep4 possess specific characters for each one. The second lake of Wadi El-Rayan was high but similar to El Wadi drain, the connecting canal of Wadi El-Rayan and the Fish Farms. The similarity of Lake Qaroun to the other localities was less than $30 \%$.

\section{2-Rotifera :}

It was represented by thirty nine species. The highest species number was observed at Wadi El-Rayan ( 33 species), while Ep 3 and Ep 4 missed the rotiferan organisms. Four species of Rotifera were euryhaline. Brachionus plicatilis and Hexaorthra oxyuris tolerated salinity ranges of 1.7-127.7 and 2.5-73.7\% respectively, while Keratella tropica and $K$ valga tolerated salinity of 1.7 to $42 \%$.

On the other side, thirteen rotiferan species were restricted to specific salinities while the others were stenohaline.

The maximum counts of Rotifera were observed at Fish Farms, Lake Qaroun and Ep1 (498067, 248039, and 737667 organisms $/ \mathrm{m}^{3}$ respectively). The most dominant species were Brachionus plicatilis and Hexarthra oxyuris, where they reached their maximum peak at Ep1.

The highest similarity ( $50 \%$ ) was between El Wadi drain and Wadi E1-Rayan Lakes, and also between Ep1 and Ep2.

\section{3 - Cladocera :}

Ten species of Cladocera were observed at El Fayoum depression, most of them could not tolerate salinity over $4.5 \%$. Two species only (Ceriodaphnia cornuta and Moina rectangula) were recorded at salinity ranges of 5.2 to $18 \%$. 
The second lake of Wadi El-Rayan encountered the highest counts of Cladocera (3647 organisms $/ \mathrm{m}^{3}$ due to the dominance of Diaphanosoma excisum ( 3639 organisms $/ \mathrm{m}^{3}$ ).

The highest similarities were observed between El Wadi drain and Wadi El-Rayan lakes.

\section{4 - Copepoda:}

Nine copepod species were observed in addition to their larvae ( nauplius and copepodite stages ). Three species are endemic to lake Qaroun ( Paracartia latisetosa, Apocyclops panamensis and Mesochra holdeti) and one is endemic to the Fish Farms (Ergasilus sieboldi).

Copepoda were absent totally at salinity over $42 \%$. The similarity between El Wadi drain, Wadi El-Rayan Lakes and the Fish Farms was the highest .

5 - Branchiopoda:

It was represented by Artemia salina. which is a marine form, recorded at salinity range of $127.7-322 \%$ with high amount at salinity of $213.3 \%$. The larvae of $A$. salina were observed at $127.7-213.3 \%$ salinity with high number.

\section{6- Tardigrada:}

It was represented by Macrobiotus macromyx that was observed at El Wadi drain and the connecting canal of Wadi El-Rayan only (salinities of 1.7 and 3 \%o).

\section{7 - Ostracoda:}

One species only (Cyprideis torosa) was observed at El Wadi drain, Wadi EI-Rayan Lakes and Lake Qaroun. 
8 - Larvae of some benthic invertebrates:

Various larvae of Polychaeta, Mollusca, Insecta, Cirripedia, and other Crustacea were recorded at El Fayoum depression and most of these larvae were found at Lake Qaroun.

\section{DISCUSSION}

The Fayoum climate is hot and dry with scanty winter rainfall and bright sunshine throughout the year. So, evaporation increases the concentration of salts in different water bodies at El Fayoum depression. Payne (1986) concluded that, Lake Qaroun can dry up to a salt pan. This was the fate of the Great Saharan Lake which was covering much of what is now desert from Niger to the Nile Valley (in pleistocene times up to perhaps 5000 years ago ). So the second lake of Wadi El-Rayan may reach to this destiny.

The species number of zooplankton decreased mostly with growing salinity levels as shown in table (7).This relation agrees with records of Chigbu ( 1987 ) in the Forcados River, Odube Creek and Warri river coastal system, and Egborge ( 1994 ) in the Lagos Harbour - Badagry Greek system (Nigeria).

The classical pattern of inverse relationship between the species number and salinity was pronounced at EMISAL ponds wherever only four species can tolerate salinity up to $73.7 \%$ and only one at salinity of $322 \%$. Most of the recorded larvae were observed in Lake Qaroun. This agrees with Morales-Baquero et al (1989), who concluded that, the lakes with high salinity harbour high numbers of benthic invertebrate larvae and periphytic species .

Some factors other than salinity were found to influence the distribution of zooplankton species (Timms, 1981), in El Wadi drain, the increases of turbidity due to clay of the agricultural lands decreased zooplankton diversity and quantity. Hart ( 1990 ) noted that the unselective feeding of Cladocera under turbid conditions allow silt to accumulate in the digestive tract and causes them to sink, whereas Jack et al (1993) suggested that , the clay may interfere with the feeding apparatus itself. In the first lake and the connecting canal of Wadi El-Rayan, incursion of submerged plants 
depression (Et-Fayoum-Egypt) )

become suitable for flourishing of zooplankton. Mageed (1992) suggested that, the high density of particulate organic matter serves as an abundant food supply for detrital filter feeders zooplankton. In Fish Farms, the fish faeces, fertilizers, and food residues leads to flourishing of phytoplankton and zooplankton (Mageed, 1996). In Lake Qaroun, the bacteriological indications of sewage pollution have reached to $16 \times 10^{12}$ cells $100 / \mathrm{ml}$ of the lake water (Sabae, 1993) due to the disposal of most of El Fayoum villages which discharge their sewage into drainage channels that lead to the lake ( EC and DCE, 1992 ). This inturn can affect zoopankton diversity. Also, many zooplankton species are transported from the Mediterranean sea during transplantation of the fries of Mugil spp to Lake Qaroun. El Maghraby and Dowidar (1969) recorded some of zooplankton species of Lake Qaroun in the Mediterranean Sea. The annual accumulation of salts from drainage water and the increases of salinity favour the development of marine zooplankton species which are introduced into the lake with the mullet fry ( Abdel Malek and Ishak, 1980 ). The environmental factors, species interaction and predation patterns have considerable effects on zooplankton community .

The main sources of zooplankton species in El Fayoum depression are mainly the drains in addition to the species which are transported with the fish fries. The circulation of zooplankton species in El Fayoum depression is shown in figure (2) .

Some species are euryhaline species that can tolerate wide ranges of salinity; as Brachionus plicatilis, Hexarthra oxyuris, Keratella tropica and $K$ valga. Galat et al (1981). Timms (1981) and Williams (1987) recorded them in Australia and North America at salinities between $0.4 \% 0$ and $50 \%$. In the Lagos Harbour, Egborge (1994) recorded B. plicatilis at salinity 0.27 $\%$ and $32 \%$. During the study, B. plicatilis was found at salinity 1.60 $127.70 \%$, where as $H$. oxyuris was at $1.50-73.7 \%$.

On the other hand, some species are stenohaline and live only at hypersaline water as Artemia salina. That was recorded at ponds of EMISAL at salinity of 127.7 to $320 \%$ with maximum counts at $213.3 \%$ salinity. Meanwhile, it was missing below these levels except its larvae which appeared at salinity of $73.7 \%$. 
Hedgpeth (1959) concluded that $A$. salina has the ability to clear the brine of salterns and improve salt production. Provassoli and Shiraishi (1959) added that, larval forms of $A$. salina are voracious, where suspended particles are quickly transformed into faecal peliets. With the highest larval production, a single shrimp daily cleared $64 \mathrm{ml}$ of water of $64 \times 10^{5}$ cells (Mason, 1962).

In conclusion, salinity of El Fayoum depression is increasing with time and this inturn has its impact on the quality and quantity of zooplankton . Therefore, the salinity changes at Wadi EL-Rayan, Lake Qaroun, and the irrigation system in EL Fayoum depression should be managed carefully.

\section{REFERENCES}

Abd el Malek, S. A. and M. M. Ishak (198). Some 0 ecological aspects of Lake Qarun, Fayoum, Egypt. Part II, Production of plankton and Benthic organisms. Hyd. 75 . 201-208.

APHA, AWWA \& WPCT (1992). Standard methods for the examination of water and waste water. $14^{\text {th }}$ ed New York.

Boraey, F. A. (1978). Preliminary studies on the ecology of the new manmade Lake, Wadi El-Rayan in the Western desert. Int. Water Fish. India PP 1-11.

Chigbu, P. (1987). The zooplankton of Warri river, Nigeria, M. Sc, Univ. of Benin, Nigeria.

Dowidar, N. M. and F. E. El Nady F.E. (1982). Chemical composition of invertebrate animals from Lake Qarun (Upper Egypt). 1-Acartia latisetosa (Kriczaguin) (Copepoda, Crustacea)Bull. Inst. Ocean. \& Fish., ARE, 8 (2). 239-256.

EC \& DCE (1992). Environmental profile, Fayoum Governorate, Egypt. Edited by Hans van Zon and Kevin W. Jeanes.

Egborge, A. B. M. (1994). Salinity and the distribution of rotifers in the Lagos Harbour-Badagry Creek System, Nigeria. Hyd- 272 . 95-104. 
EL Maghraby, A. M. \& Dawidar, N. M. (1969). The occurrence of marine plankton organisms in Lake Qarun ( Egypt). Commission Int. Pour L' expt. Seie. de la Mer Medit., Monaco, 19 . 849-851.

Galat, D. L., E. L. Lider; S. Vigg \& S. R. Robertson (1981). Limnology of a large deep, North American Lake, Pyramid Lake, Nevada. Hyd. 82.281-317.

Girgis, R. B. (1960). Okolgische Untersuchungen in Lake Qarun (Agypten). issertation, Univ. Kiel.

Green, J. (1971). Associations of Cladocera in the zooplankton of the lake Sources of the White Nile. Proc. Jour. Zool. Soc. Lond., 165 . 373-414.

Hart, R.C. (1990). Zooplankton distribution in relation to turbidity and related environmental gradients in a large subtropical resevoir. patterns and implications. Fresh Water Biology, 24 . 241-263.

Hedgpeth, J. W. (1959). Some preliminary considerations of the biology of inland mineral waters. Archivio Oceanogr. Limnol., 11 (Suppl.). 111141.

jack, J.D.; Wickham S. A.Oalson ; S. T. and Gilbert J. J. (1993). The effect of clays on a Fresh water plankton community. An enclosure experiment. Arch. Hyd., 127 (3) . 257-270.

Khalifa, N. E. (1994). Studies on Zooplankton of Lake Qaroun. M. Sci., thesis, Fac. of Sci., Cairo Univ., 180 pp.

Khalil, M. T. (1978). Ecological and biological studies on zooplankton of take Qarun in Fayoum with special reference to Crustacea. M.Sc. thesis. Ain Shams Univ. Cairo, PP. 1-139.

Khalil, M.T. (1984). Studies on the population dynamics of animal organisms and effect of pollutants upon some of them in Lake Wadi El Rayan (El Fayoum, Egypt ). Ph. D. Thesis. Fac. of Sci., Ain Shams Univ. 79 pp 
Mageed, A. A. (1992). Ecological studies on zooplankton from Khor El Ramla (Lake Nasser), M.Sc. thesis, Fac. Sci. Al Azhar Univ.

Mageed, A. A. (1996). Zooplankton assemblages and their role as natural food for the cultivated fishes in El Fayoum fish farms-Egypt. Bull. Fac. Sci, Zag. Univ., 12 (2). 330-341.

Mason, M. (1962). The growth response of Artemia salina (L) to various feeding regimes. Contribution no. 1212 from the woods Hole Ocea. Inst.

Mc Naughton, S. J. (1968). Structure and function in Californian grasslands. Ecology., 49 . 962-972.

Morales-Baquero, R; L. Cruz-Pizarro, and P.Carrillo (1989). Patterns in the composition of the rotifer communities from high mountain Lakes and ponds in Sierra Nevada ( Spain ). Hyd., 186, 187. 215-221.

Naguib, M. (1961). Studies on the ecology of Lake Qarun (Fayoum. Egypt). Part 2. Kiel Meerestorach, 17 (1). 94-131.

Payne, A. T. (1986). The ecology of tropical lakes and rivers. John Wiely \& Sons. Chichester, New york. Tornto, Brisbane and Singapore 300 pp.

Provasoli, L. \& K. Shiraishi (1959). Axenic cultivation of the brine shrimp Artemia salina. Biol. Bull., 117 . 347-355.

Rabeh, S. A. (1996). Bacteriological and chemical studies on benthic layers of Wadi El Rayan Lakes, Fayoum, Egypt. Ph.D. Thesis, Fac. of Sci., Tanta Univ.

Sabae, S. Z. (1993). Studies on aquatic bacteria in Lake Qaroun, Fayoum, Egypt. M.Sc. thesis, Fac. Sci, Tanta Univ..

Sabae, S. Z. (1996). Bacteriological and chemical studies on benthic Layers of Lake Qaroun, Faiyum, A.R.ggypt. Ph. D. Thesis, Fac. of Sci., Tanta Univ. 
Distrlbution and salinity ranges of zooplankton organisms at El- Fayoum

depression (Et-Fayoum-Egypt)

Saleh, M. A. (1984). Reports (1-3) on ecological investigation of inorganic pollutants in El Fayoum. Wadi El Rayan aquatic environment. Grant FRCV 842020 Fac. of Agriculture, Cairo Univ.

Shannon, C. E and W.Weaver; (1963). The mathematical theory of Communication. Uni. of Illinois, Urbana..

Shebrawy, G. M. (1993). Studies on the invertebrates in Wadi El-Rayan depression. M. Sc. Thesis, Fac of Sci., Zag. Univ., Egypt.

Timms, B. V. (1981). Animal communities in three Victorian Lakes of different salinities, Hyd. 8I . 181-193.

Williams, W. D. (1978). Limnology of Victorian Salt Lakes. Verh. Int. Limnol. 20.1162-1174.

Wimpenny, R. S. and Titterington (1936). The ova and larvae of M.Capito Cuv. from Lake Qarun, Egypt. Ann. Mag. Nat. Hist., Ser. 10,17. 405413 


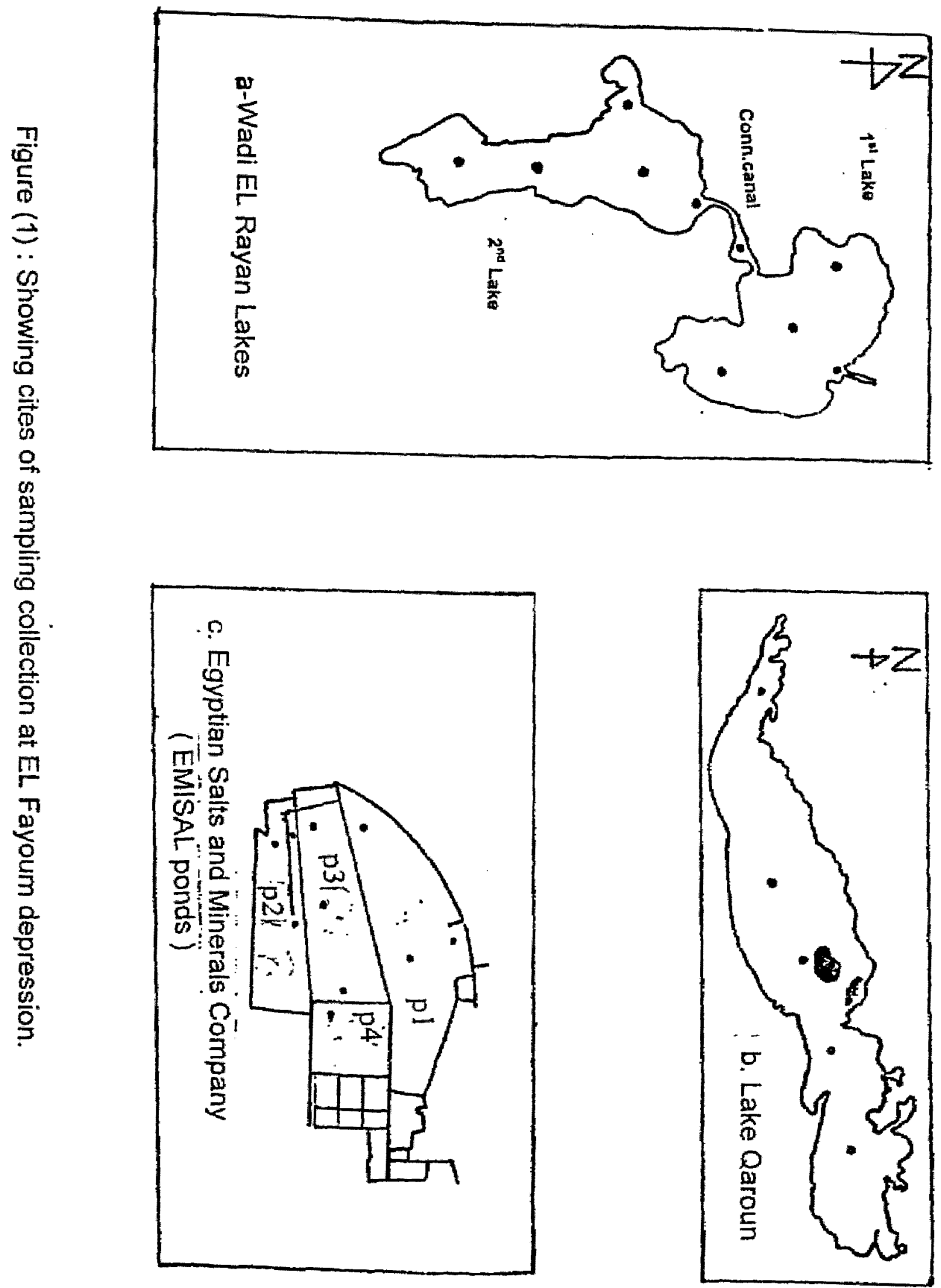




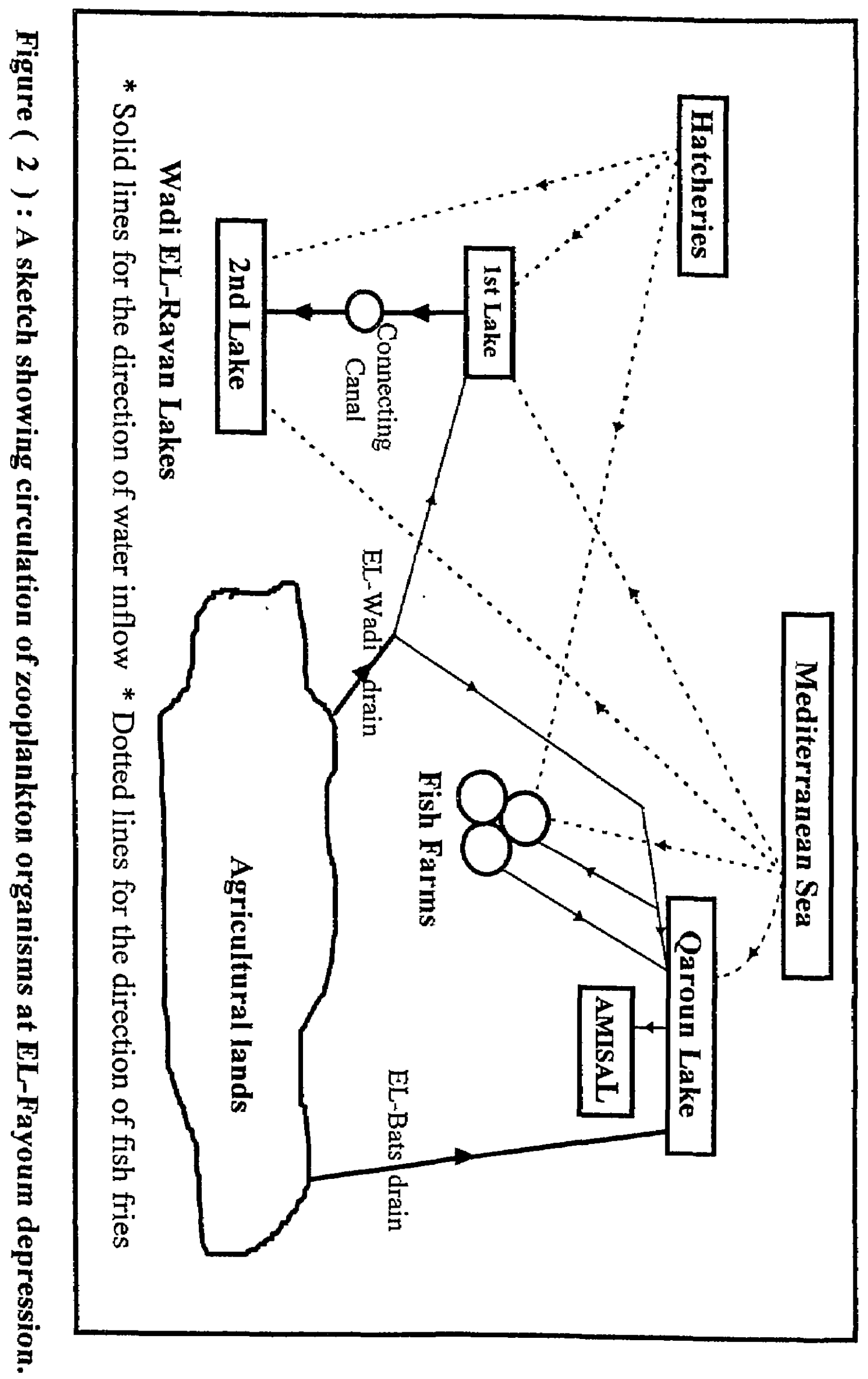


Table (1): Salinity (\%), of the different water masses of El Fayoum depression during 1996.

\begin{tabular}{|lr|c|l|}
\hline \multicolumn{2}{|c|}{ Sites } & Salinity(\%o) & \multicolumn{1}{|c|}{ Authors } \\
\hline El Wadi drain & 1.7 & Rabeh (1996)\& Sabae (1996) \\
\hline \multirow{2}{*}{ Wadi El-Rayan } & conn. canal & 3.0 & Rabeh ( 1996) \\
& $2^{\text {nd }}$ lake & 4.5 & \\
\hline Fish Farms & & $5.2-18$ & Mageed (1996) \\
\hline Qaroun Lake & & 42.0 & Sabae (1996) \\
\hline \multirow{3}{*}{ EMISAL Ponds $\quad 2^{\text {nd }}$ pond } & 127.7 & Present study \\
& $3^{\text {rd }}$ pond & 213.3 & \\
& $4^{\text {th }}$ pond & 322.0 & \\
\hline
\end{tabular}




\begin{tabular}{|c|c|c|c|c|}
\hline 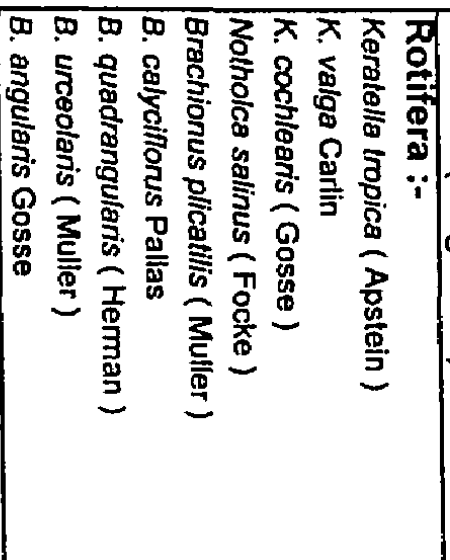 & 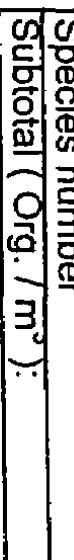 & 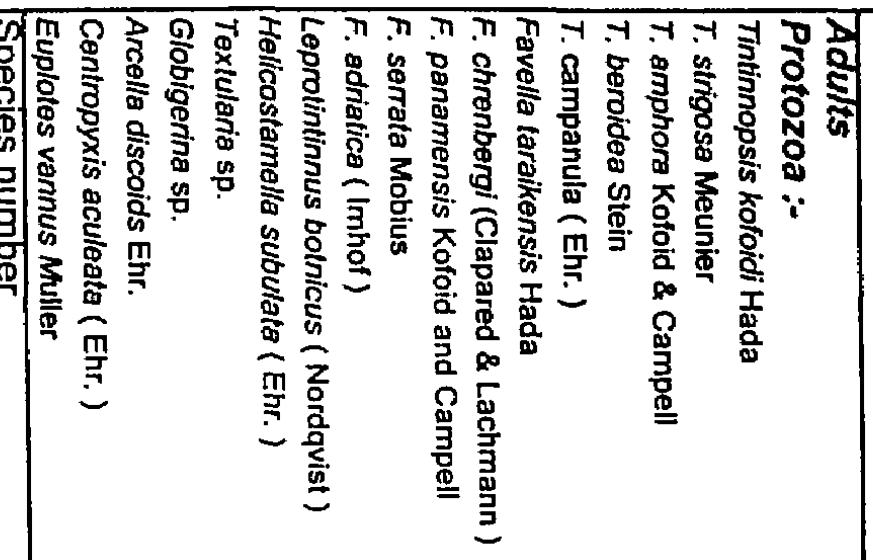 & $\begin{array}{l}\frac{\infty}{8} \\
\frac{8}{8} \\
\frac{8}{8}\end{array}$ & \\
\hline $0 \circ \tilde{\sigma} \stackrel{\omega}{\rightarrow} \sim \vec{\infty} \underset{\exists}{\vec{\nu}}$ & $|\overrightarrow{\mathrm{G}}|+$ & $A 0$ वै & 总 & \\
\hline ○ & 0.0 & $0 \mid 000000000000000000$ & 1" Lako & $\leq$ \\
\hline 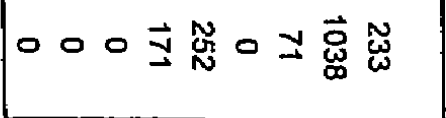 & $\mid \begin{array}{ll}0 \\
\mathrm{\omega} \\
\mathrm{\omega}\end{array}$ & $-0 \stackrel{N}{0} \vec{V} \vec{N} 0000000000000$ & Conn.canal & $\mid \begin{array}{l}\mathrm{II} \\
\mathbf{2} \\
\mathbf{⿴ 囗 十}\end{array}$ \\
\hline Ow & 曾 & $\omega \mid \infty \omega \vee N 0000000000000$ & $2^{\text {nat Lako }}$ & \\
\hline 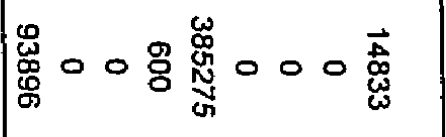 & $\left|\begin{array}{c}5 \\
\$ \\
⿱ 亠 乂\end{array}\right|+$ & $A \vec{\Phi} \vec{\nabla} 0$ N & 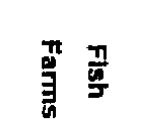 & \\
\hline 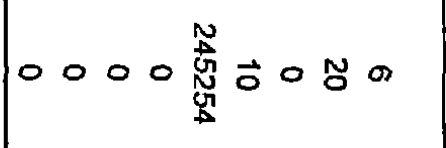 & $\mid$ & 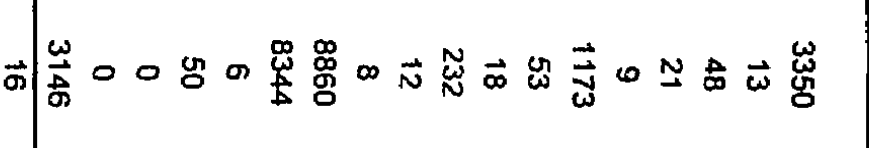 & 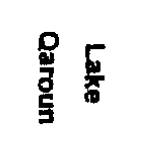 & \\
\hline 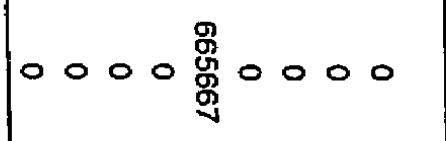 & $|\vec{y}|$ & 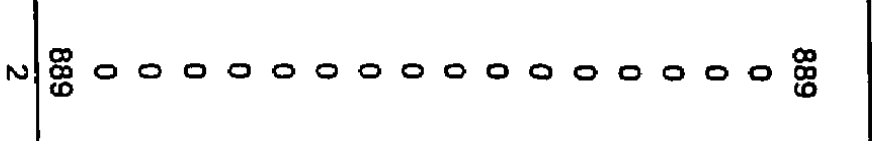 & I" Pond & \\
\hline $0000 \underset{\omega}{W} 0000$ & $\mid$ & -000000000000000000000. & $2^{\text {nd pond }}$ & 3 \\
\hline 000000000 & 0 & 01000000000000000000 & $3^{\text {red Pond }}$ & 号 \\
\hline 000000000 & 0 & 0000000000000000000 & $4^{m}$ Pond & \\
\hline
\end{tabular}




\begin{tabular}{|c|c|c|}
\hline 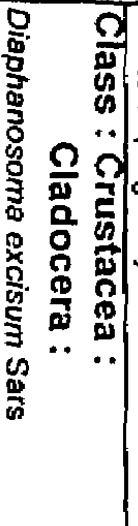 & 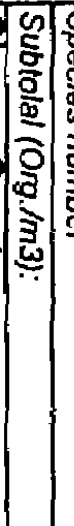 & 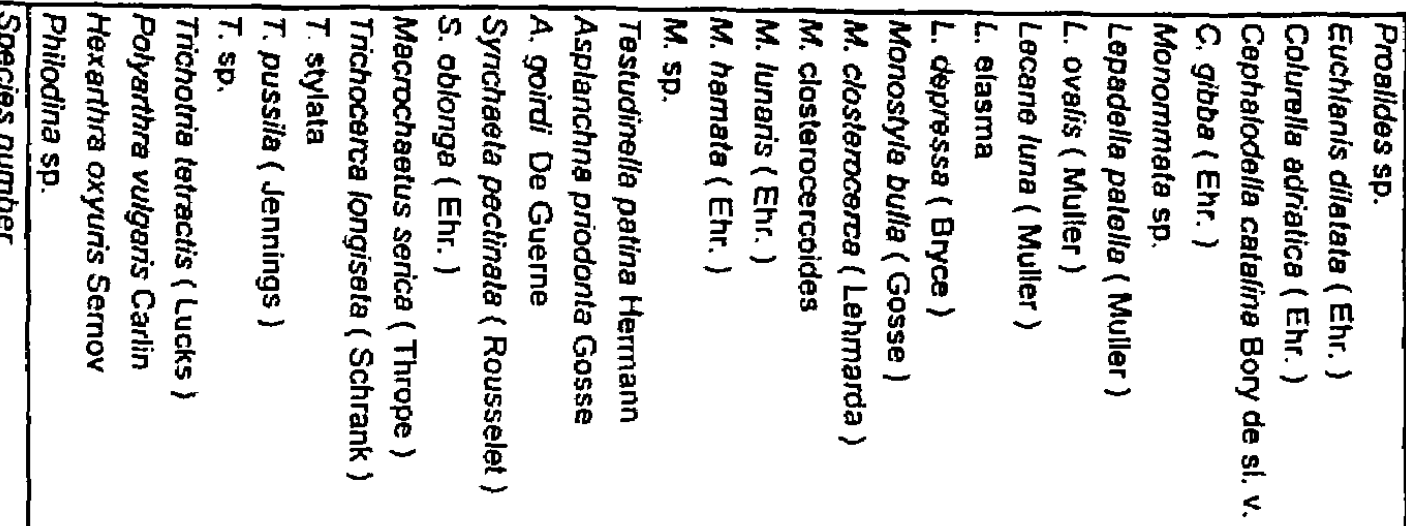 \\
\hline 옹 & 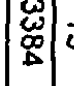 & 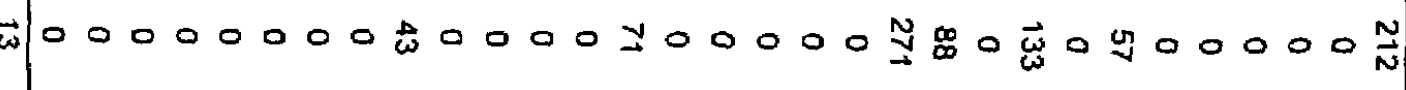 \\
\hline 昌 & $\left|\begin{array}{c}\text { ज़ै } \\
\mid\end{array}\right|$ & 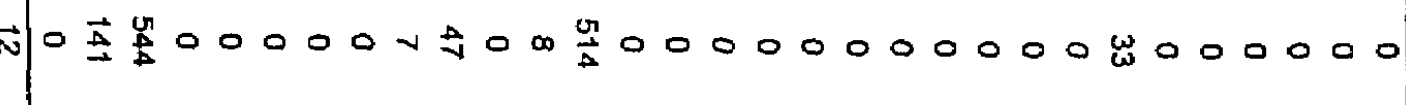 \\
\hline $\overrightarrow{\mathrm{N}}$ & | & 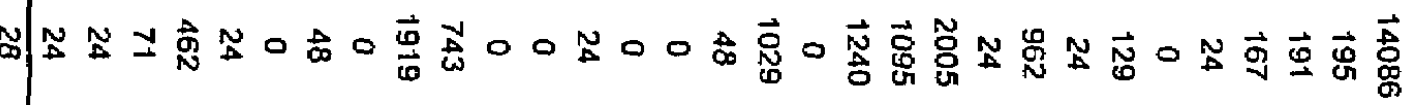 \\
\hline$\underset{\mathscr{g}}{\omega}$ & 空 & 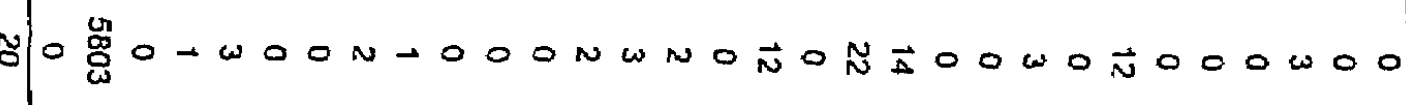 \\
\hline 0 & 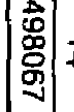 & 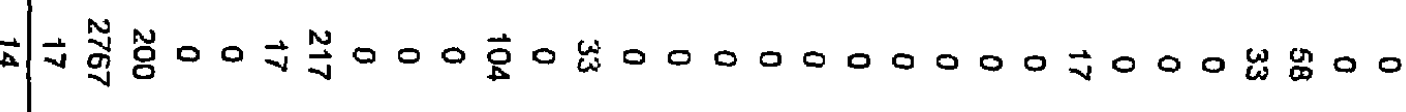 \\
\hline 0 & | & $00 \frac{\pi}{ \pm} 00000000 \underset{\omega}{\omega} 000000 \vec{N} 0000000000000$ \\
\hline 0 & 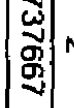 & No 000000000000000000000000000000 \\
\hline 0 & $\left|\begin{array}{c}|c| c \\
\omega\end{array}\right|$ & 0000000000000000000000000000000 \\
\hline 0 & 10. & 010000000000000000000000000000000 \\
\hline 0 & 0 & 00000000000000000000000000000000 \\
\hline
\end{tabular}




\begin{tabular}{|c|c|c|c|c|c|c|c|c|c|c|}
\hline 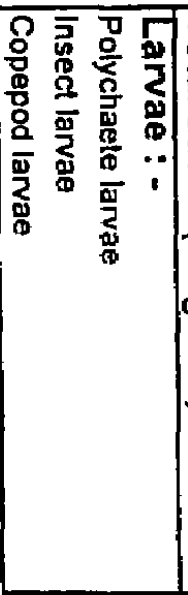 & 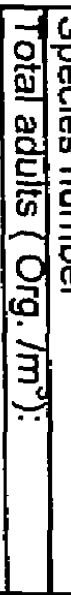 & 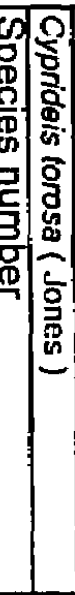 & 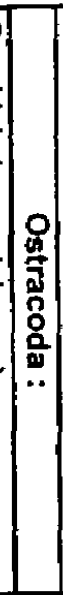 & 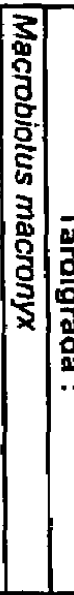 & 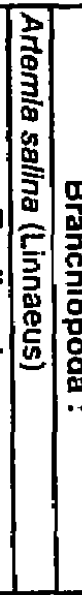 & 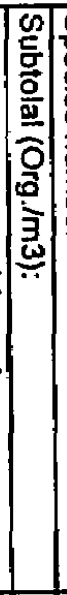 & & 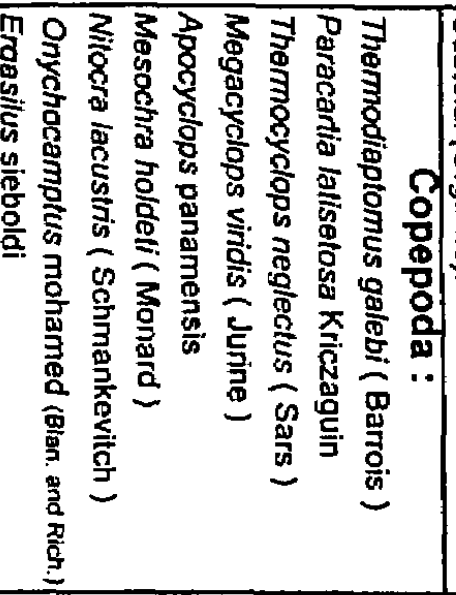 & \begin{tabular}{l|l}
0 \\
0 \\
0
\end{tabular} & 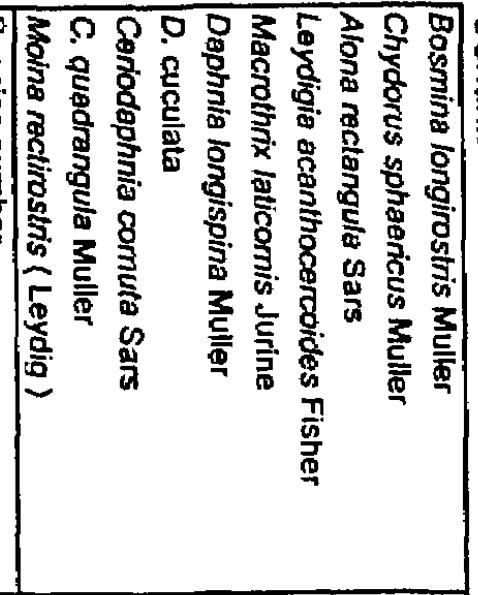 \\
\hline 绐 & : & w) & & 炱 & 이 & ज্స: & $\omega$ & $0 \vec{\omega} \circ 00 \overrightarrow{0} 00 \%$ & $|\vec{\omega}|=$ & 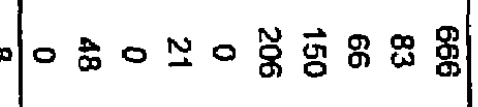 \\
\hline 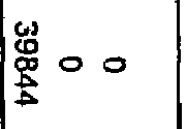 & $\mid \begin{array}{l}0 \\
\mathbf{a} \\
\mathbf{g} \\
\mathbf{\omega}\end{array}$ & s. & & 0 & 아 & 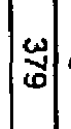 & $\omega$ & 000000. & 勇 & $M \circ$ 䙳 0 若 \\
\hline 惫 总 o & $\mid$ & $\pm \overrightarrow{\mathrm{g}}$ & & 昜 & 0 & 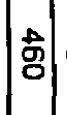 & $\omega$ & 0 岕 000 咅 00 & $\mid \overrightarrow{\mathbf{N}}:$ & 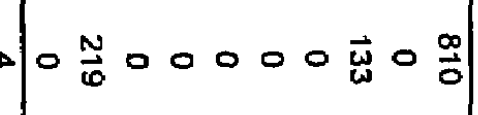 \\
\hline 产 wo & $|\overrightarrow{\overrightarrow{\vec{A}}}|$ & $\vec{G} \vec{G}$ & 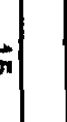 & 0 & 이 & W్ & $\omega$ & ONVONOOOON & $\mid \begin{array}{l}\text { Wh } \\
\text { 岁 }\end{array}$ & $0-0,0,0 N n-$ \\
\hline$\stackrel{\infty}{\frac{\infty}{\nu}} \circ \vec{g}$ & $\left|\begin{array}{c}0 \\
\overrightarrow{0} \\
0 \\
\vdots \\
\vdots\end{array}\right|$ & U. & & 0 & 0 & 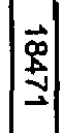 & an & 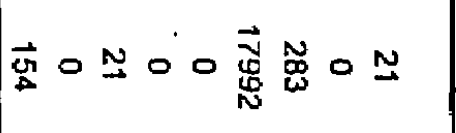 & $|\stackrel{\infty}{\nabla}| r$ & 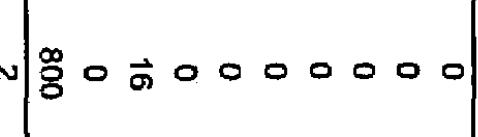 \\
\hline 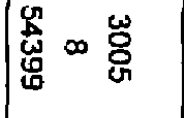 & $\mid$ & Nat & & 0 & 인 & $\overrightarrow{\mathrm{n}}$ & $\omega$ & $000 \omega \omega 00$ 点 0 & 00 & 0.0000000000 \\
\hline N & $\left|\begin{array}{c}0 \\
0 \\
0 \\
⿱ \\
\text { जे }\end{array}\right|$ & $\rightarrow 0$ & & of & 0 & 이 & 0 & 000000000 & 0. & 00000000000 \\
\hline og & $\mid$ & $\omega$ & & 이 & $\mid$ & o & 이 & 000000000 & 00 & $0 \mid 00000000000$ \\
\hline 000 & : & -0 & & 0 & 。ิ & 0 & 0 & 000000000 & 0,6 & $0 \mid 0000000000$ \\
\hline 000 & $\mid$ & $-\infty$ & o) & 0 & N & 이 & 0 & 000000000 & 0 & 00000000000 \\
\hline
\end{tabular}



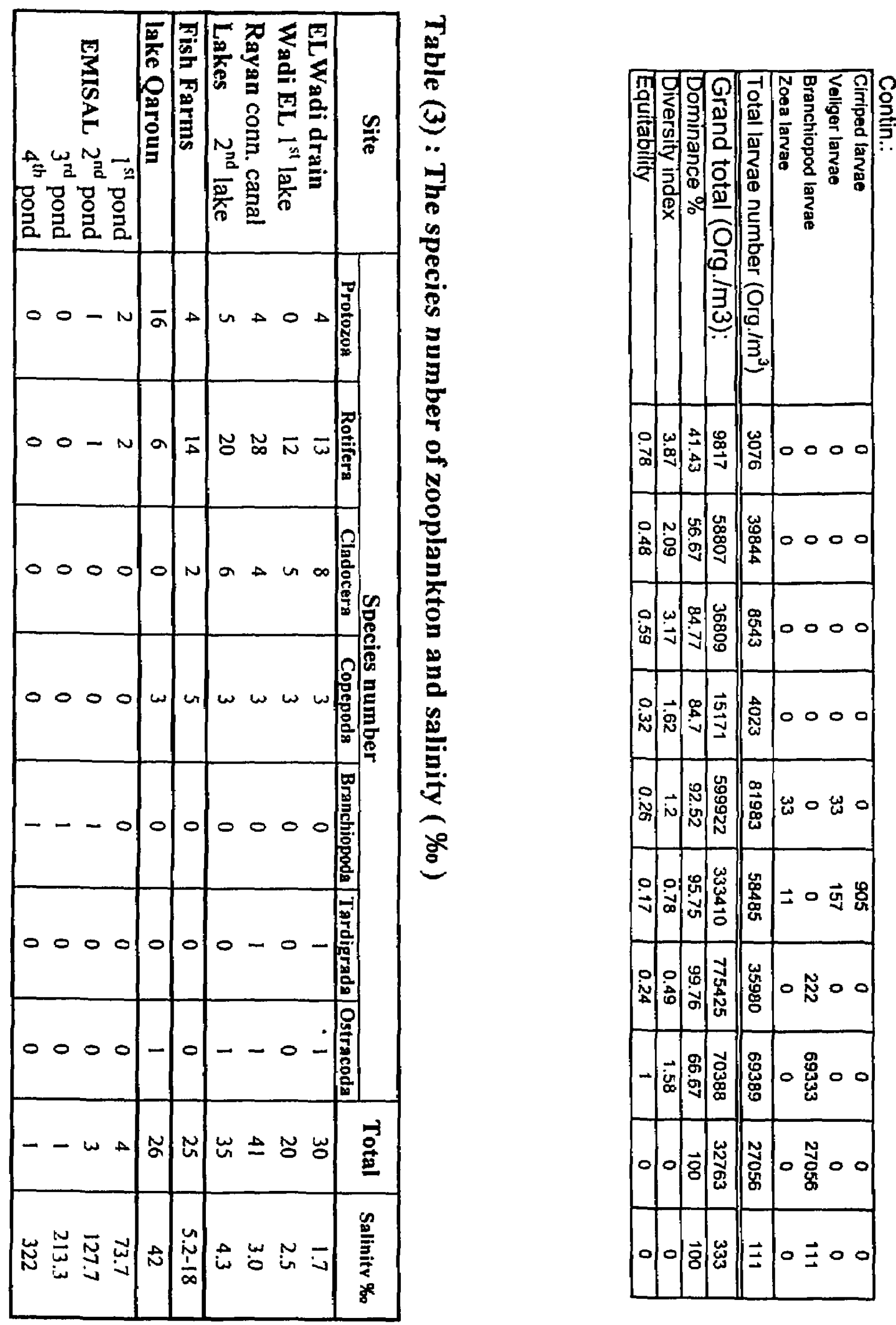


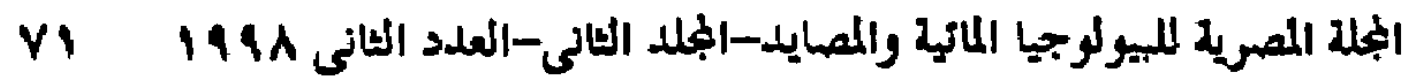

درجات الملرحة وتوزيع المرالت الميرانية في منغفض الثفيرم ( الفيوم - مصر)

عادل على أملد عبد الجيد.

المعهد القوبى للموم البمار والمصايد

تم دراسة توزيع العوالق الحميوانية فى منحفض الفيوم (مصرف ألوادى) وبحيرات وادى الريسان

والمزأرع السمكية وبكيرة قارون واحواض ثركة (اميسال) مذا بالاضافة إلى أنه تم تحديد مـدى تحمل

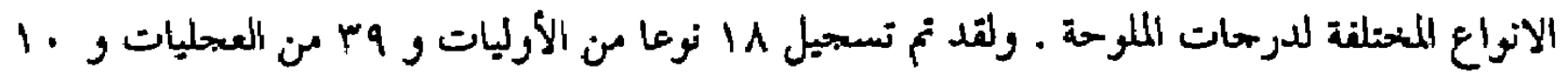

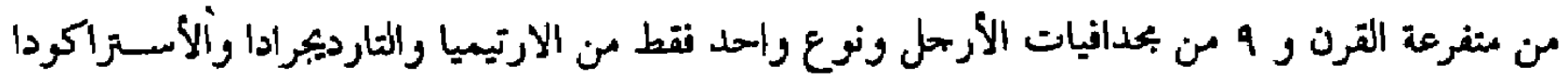

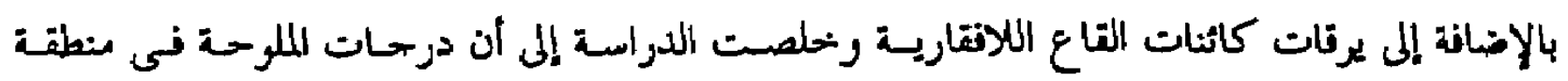

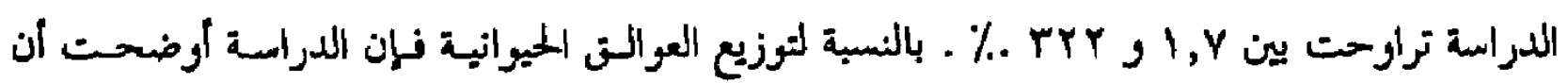

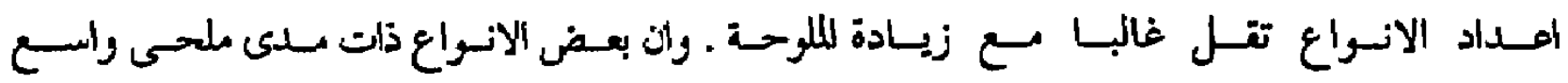
مثل (\%

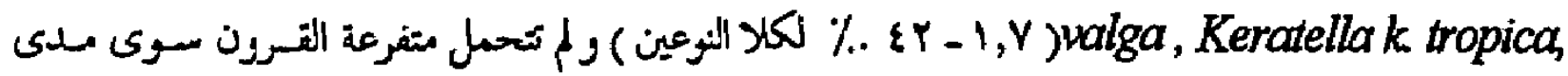

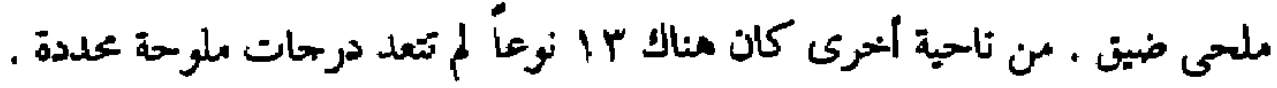

